\title{
Physical properties of shelled maize (Zea mays L.) cobs
}

\author{
Singh, I., ${ }^{1}$ Singla, M., ${ }^{2}$ 雨 Goraya, R. K., ${ }^{3}$
}

Received: 22.10 .2020

Revised: 13.12.2020

Accepted: 06.01.2021

\begin{abstract}
Gasification is an effective technology for the formation of producer gas from biomass with least greenhouse gas emissions. The aim of this investigation was to analyze the physical properties of shelled maize cobs. The length, moisture content and bulk density of maize cobs were determined as per the standard procedure. It was found that range of length, moisture content and bulk density of maize cobs was suitable for being used in a downdraft gasifier.
\end{abstract}

Key Words: Bulk density, Maize cobs, Moisture content, Physical properties

\section{Introduction}

Corn (Zea mays L.) is the most important cereal crop belongs to the Poaceae family. During the corn processing, it yields about $50 \%$ stalk, $22 \%$ leaves, $15 \%$ cobs and $13 \%$ as kernels (Sokhansanj et al., 2002 and 2010). Corn stalks and leaves are produced at the farm level while cobs are generated at the processing unit. Cobs have several advantages as compared to other biomass materials as it is dense, high energy content as well as low nitrogen and sulfur concentrations. Moreover, cobs can also be used as a source of energy by converting it thermo-chemically through gasification and pyrolysis (Kumar et al., 2008).

For efficient operation and design of thermochemical conversion systems, physical properties (size, bulk density and moisture content) of maize BIOMASS need to be measured. The performance of thermochemical conversion systems was greatly influenced by the physical properties of biomass. The optimum size and moisture content of the biomass yields higher performance (Singla et al., 2020; Bhutiani and Ahamad, 2019). High moisture content reduces the heating value of biomass fuel that further leads to a reduction in conversion efficiency. Even the biomass with high calorific value, if used in inadequate size, can yield deprived efficiency. The bulk density influences the transportation,

\section{Author's Address}

${ }^{1}$ Department of Renewable Energy Engineering, Punjab Agricultural University, Ludhiana

${ }^{2,3}$ Department of Processing and Food Engineering

Punjab Agricultural University, Ludhiana-Punjab, India

E-mail.: mohit-sree@pau.edu storage and biomass feed into thermochemical conversion systems. The aim of the present study is to analyze the physical properties of shelled maize cobs.

\section{Material and Methods}

Cobs (Zea Mays L., variety: PMH-1) were procured from the field of Department of plant breeding and genetics (Maize section), Punjab Agricultural University and shelled maize cobs were approximately cylindrical in shape as shown in Fig. 1. The physical properties as size, bulk density and moisture content of maize cobs were determined experimentally. The methods used to determine the properties are described in detail below:

Size: The shelled maize cobs were normally $10-15$ $\mathrm{cm}$ long. For gasification in downdraft gasifier with the throat, cobs were required to reduce to a length of 5.5-8 cm, which was done manually. The length of 10 number maize cobs was measured using the measuring scale, and average values have been reported.

Moisture content: Hot air oven drying technique was used to measure the moisture content (MC), in which the known weight of the sample was kept at $105{ }^{\circ} \mathrm{C}$ till the variation between two consecutive observations became unchanged (Sahay and Singh, 2001). Moisture content (\% w.b.) was calculated using the Eqn. 1 and expressed as \%, wb. 
$M C(\%, w b)=\frac{W_{i}-W_{f}}{W_{i}} \times 100$

where, $\mathrm{W}_{\mathrm{i}}=$ initial weight, $\mathrm{g}$,

$\mathrm{W}_{\mathrm{f}}=$ final weight, $\mathrm{g}$

Bulk density: It is the ratio of the weight of the bulk of biomass material to the volume occupied by it in a known volume container. Bulk density was measured using the mass of cobs occupied in $1000 \mathrm{ml}$ beaker. Bulk density (BD) was estimated using Eqn. 2 and expressed as $\mathrm{kg} / \mathrm{m}^{3}$.

$$
B D\left(k g / m^{3}\right)=\frac{\text { Mass }}{\text { Bulk voulume }}
$$

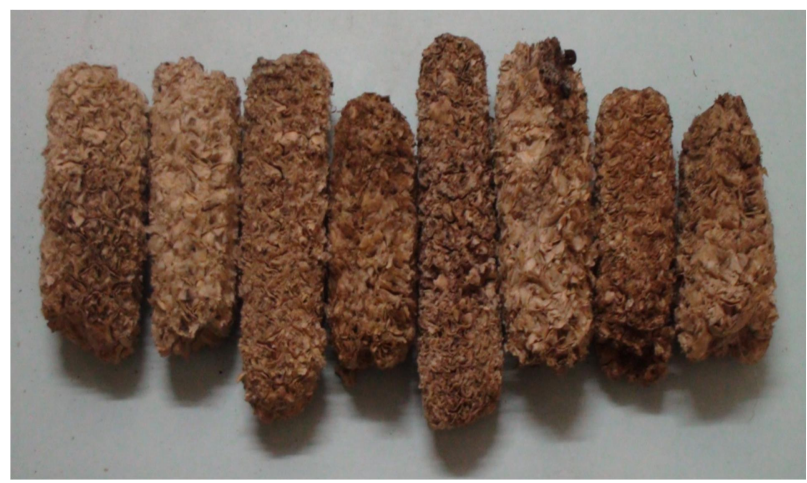

Figure 1. Shelled maize Cobs

\section{Results and Discussion}

The physical properties of shelled maize cobs were summarized in Table 1. Size of feedstock is an important parameter, which affects gasification because larger particles tend to cause bridging and prevent the downward movement of feedstock in the gasifier. The average length of maize cobs was found to be $5.9 \mathrm{~cm}$. The moisture content of biomass greatly affects both the operation and the quality of producer gas. The average moisture content of maize cobs was observed as $6.94 \%$. Higher the moisture content of biomass feedstock requires more air to maintain process temperature resulting in lower gasification efficiency. The moisture content of biomass below $15-18 \%$ has been reported to be suitable for downdraft gasifier. The average bulk density of maize cobs was found to be $147 \mathrm{~kg} / \mathrm{m}^{3}$. Higher bulk density biomass requires less reactor space for a given refuelling time, whereas low bulk density fuels give rise to insufficient flow under gravity. Therefore, biomass with bulk density in the range of $100-300 \mathrm{~kg} / \mathrm{m}^{3}$ gives rise to sufficient flow in the reactor (Dogru et al., 2002).

Table 1. Physical properties of shelled maize cobs

\begin{tabular}{|l|l|}
\hline \multicolumn{2}{|c|}{ Physical properties } \\
\hline Length $(\mathrm{mm})$ & $5.9 \pm 0.25$ \\
\hline Mass $(\mathrm{g})$ & $9.61 \pm 1.37$ \\
\hline Moisture content $(\% \mathrm{wb})$ & $6.94 \pm 0.11$ \\
\hline Bulk density $\left(\mathrm{kg} / \mathrm{m}^{3}\right)$ & $147.00 \pm 6.53$ \\
\hline
\end{tabular}

Note: Average \pm SD values

\section{Conclusion}

The physical properties of shelled maize cobs were measured to evaluate their suitability as fuel for gasification. The average length, moisture content and bulk density of maize cobs were $5.9 \mathrm{~cm}, 6.94 \%$ and $147 \mathrm{~kg} / \mathrm{m}^{3}$ respectively. The average length, moisture content and bulk density indicated that it could be used as gasification.

\section{References}

Dogru, M., Howarth, C. R., Aka, G., Keskinler, B. and Malik, A. A. 2002. Gasification of hazelnut shells in a downdraft gasifier. Energy, 27: 415-27.

Kumar, A., Wang, L., Dzenis, Y. A., Jones, D. D. and Hanna, M. A. 2008. Thermogravimetric characterization of corn stover as gasification and pyrolysis feedstock. Biomass and Bioenergy, 32: 460-467.

Sahay, K. M. and Singh, K. K. 2001. Unit operations of agricultural processing. Vikas Publishing House Pvt. Ltd, pp-109.

Singla, M., Singh, M. and Dogra, R. 2020. Experimental investigation of imbert downdraft gasifier using rice strawn briquettes. Energy Sources Part A: Recovery, Utilization and Environmental Effects,

Sokhansanj, S., Mani, S., Tagore, S. and Turhollow, A. F. 2010. Technoeconomic analysis of using corn stover to supply heat and power to a corn ethanol plant - Part 1: Cost of feedstock supply logistics. Biomass Bioenergy, 34: 7581.

Sokhansanj, S., Turhollow, A., Cushman, J. and Cundiff, J. 2002. Engineering aspects of collecting corn stover for bioenergy. Biomass Bioenergy, 23: 347-355. 